\title{
AERODYNAMIC AIRFOIL AT CRITICAL ANGLES OF ATTACK
}

\author{
Čedomir Lj. Kostića ${ }^{a}$ Boško P. Rašuo ${ }^{b}$ \\ ${ }^{a}$ General Staff of the Serbian Army, AF\&AD, 204.vbr, \\ Batajnica, Republic of Serbia, \\ e-mail: cedokostic@gmail.com, \\ ORCID iD: - Thttp://orcid.org/0000-0001-9940-3560 \\ ${ }^{b}$ University of Belgrade,Faculty of Mechanical Engineering, \\ Belgrade, Republic of Serbia, \\ e-mail: brasuo@mas.bg.ac.rs, \\ ORCID iD: http://orcid.org/0000-0002-0912-6844
}

FIELD: Mechanical Engineering

DOI: $10.5937 /$ vojtehg64-8048 ARTICLE TYPE: Review Paper ARTICLE LANGUAGE: English

\section{Summary:}

Aircraft construction experts must not neglect the behavior of aircraft in extreme or closely extreme flight conditions, such as flights at critical angles of attack, where a normal flight can be easily converted into a stall.

This paper highlights the essential factors that influence the behavior of aircraft in flight at critical angles of attack. Based on the available experimental results and estimations, the performances of airfoils were analysed depending on air flow conditions (categorized according to Mach and Reynolds numbers), airfoil shapes, dynamics of the transition of angles of attack, description of the flow around airfoils with increasing the angle of attack upon reaching a critical value, and the effect of roughness of airfoil surfaces at critical angles of attack.

The paper gives a physical interpretation of a lift decrease and a stall. It minutely describes the origin of flow separation and categorizes airfoil sections by type of separation and their behavior during the flow at the critical angle of attack.

Based on modern aerodynamics, this paper aims to show and explain the issues and the most important characteristics of the flow past the body at critical angles of attack and give practical recommendations for airfoil design. As such, it may be of interest to pilots and engineers as well as to educational and research institutions.

Key words: aerodynamic, performance of airfoils, fluid dynamics, airfoil shape, critical angles of attack. 


\section{Introduction}

A value of the lifting force of the wing (of a body in flow) obtained at the moment when further increase of the angle of attack ( $\alpha$ ) does not increase it any more is called the maximum lift force of the body for given flow conditions (Gretchikhin, 2014). The angle of attack at which separation of the laminar flow occurs on the curverepresents the point of falling of the $C_{L} / \alpha$ curve angle (chart $C_{L} / \alpha$ Figure 1 ).
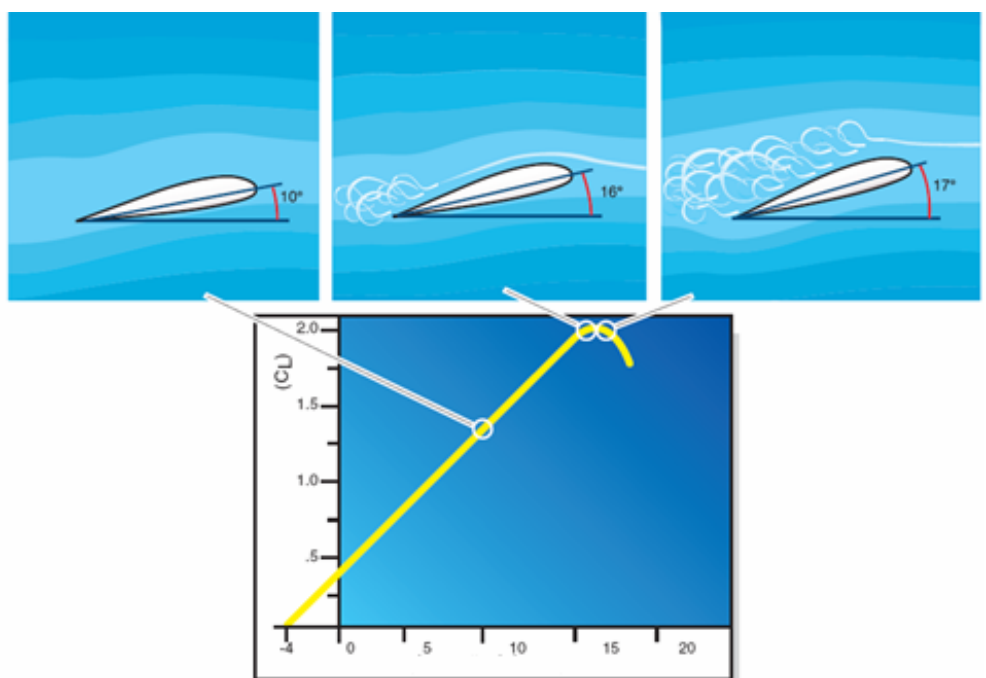

Figure 1 - Change of the lift coefficient $C_{L}$ when increasing the angle of attack $\alpha$ Puc. 1 - Изменение коэффициента подъемной силы $C_{\llcorner}$при увеличении угла атаки $\alpha$

Slika 1 - Promena koeficijenta uzgona $C_{L}$ sa povećanjem napadnog ugla $\alpha$

A value of the angle attack at which the lift coefficient has the maximum value represents the angle of the maximum lift. A further increase of the attack angle causes that the lift force decreases slowly in the beginning, then more steeply. For certain values of the angle of attack $\left(\alpha_{\kappa p}\right)$, the lift force is lost.

The maximum lift depends on various factors:

- Airfoil shape (of a body in flow);

- The flow conditions (modeled by Reynolds and Mach numbers);

- The shape of the wing (of a body in flow), slenderness, the position of the wings in relation to the flow and the aircraft fuselage (the angle of the arrow, curl wings);

- Aerodynamic additions to wings;

- The engine; and

- Flight dynamics of the body. 
The value of the maximum lift coefficientis a complex function that depends on the geometric size of the airfoiland the Reynolds number; therefore, it cannot be calculated analytically. The wind tunnel testing has led to the empirical equations that apply to a specific area of the Reynolds number, so that usual airfoils for approximate calculations can be determined from the equation:

$$
C_{z \max }=1.73-2.4\left[1-14\left(\frac{d}{l}\right)_{\max }+50\left(\frac{d}{l}\right)^{2}\right]+2\left(\frac{c}{l}\right)_{\max }
$$

The above formula applies to the value of $\operatorname{Re}=3 \cdot 10^{6}$, while for other values of the Reynolds number it is necessary to make corrections.

An approximate value of the critical angle of attack is obtained from the equation:

$$
a_{\max }=\left(11+a_{n}\right)+50\left(\frac{d}{l}\right)_{\max }+70\left(\frac{c}{l}\right)_{\max }
$$

As shown in Figure 2, $\mathrm{C}_{\mathrm{Ix}}$ is from 1.5 to 1.6 , i.e. less than $10 \%$ of the theoretically possible values (Cone,1985).

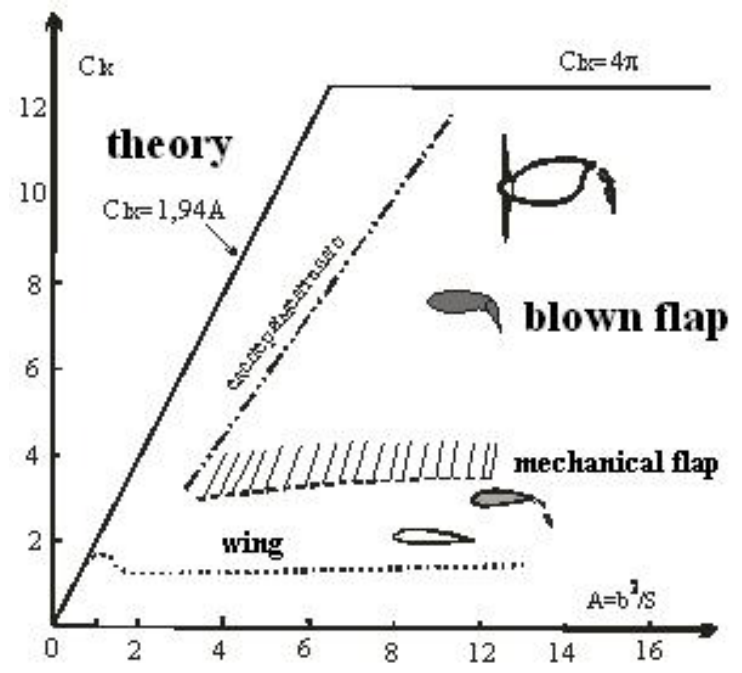

Figure 2 - Potential maximum lift force coefficient Puc. 2 - Потенциальное максимальное значение коэффициента подъемной силы Slika 2 - Potencijalni maksimalni koeficijent uzgona

With aerodynamic accessories (slats and flaps) and an additional impact of jet (engine), the values of about $30 \%$ of the theoretical value are obtained. 


\section{The physical interpretation of a stall}

An increase in the angle of attack observed along the airfoil leads to the following:

- Large vacuum near the leading edge;

- Strong positive pressure gradient between the negative peak and the trailing edge;

- Increase of the boundary layer along the upper side of the airfoil.

An increase of the angle of attack of the flow at the airfoil crosssection leads to two critical points in the stream where the separation of flow can be expected:

1. At the leading edge, where a streamline must flow around the attack "nose", which corresponds to a loss of momentum;

2. In the vicinity of the trailing edge, where there is a noticeable increase in the thickness of the boundary layer.

The loss of lift due to the separation of flow occurs in one of these points or at both points at the same time. In Figure 3, the CL- $\alpha$ diagram (Kostić, 2010) shows three specific ways of flow separation.

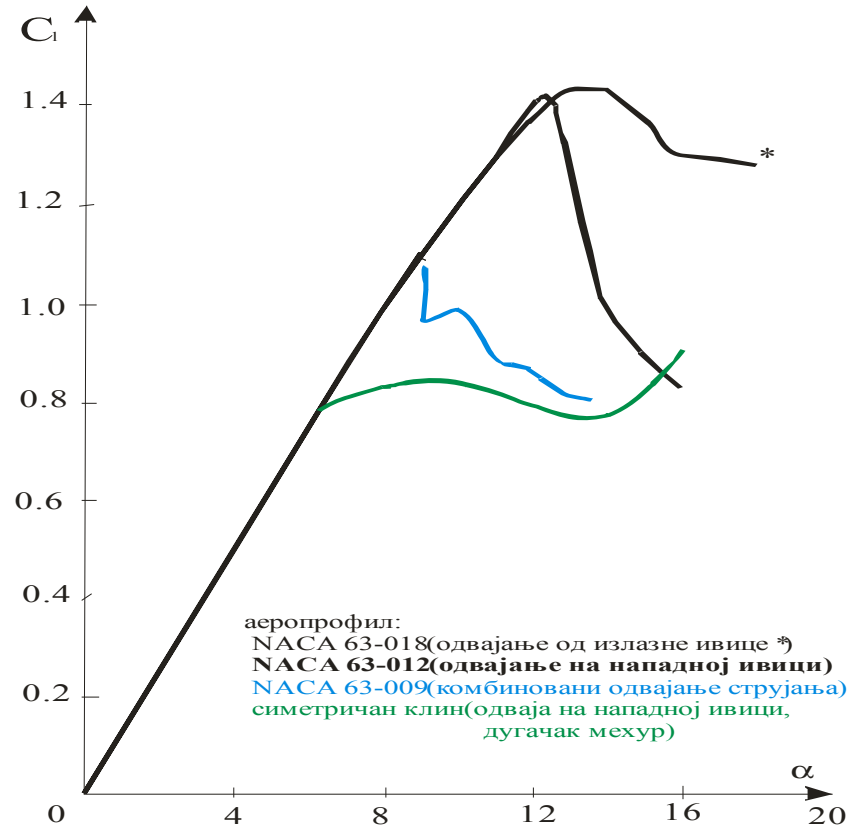

Figure 3 - Types of the separation flow of the A-profile, $R e=5.8 \cdot 10^{6}$

Puc. 3 - Виды срыва потока на A-профиле, $R e=5,8 \cdot 10^{6}$

Slika 3 - Tipovi otcepljenja strujanja A-profila, $R e=5,8 \cdot 10^{6}$

The selection included the airfoils whose $C L-\alpha$ curve values coincide up to $\alpha \approx 60$, after which there is a characteristic discrepancy. 


\section{Separation from the leading edge - elongated bubble shapes}

Separation from the leading edge isgradually formed on thinner airfoils with relatively sharp leading edges, as a form of an elongated laminar separation bubble;

Adouble-fold curve, characteristic for flow separation at the leading edge in a shape ofelongated bubbles, ca be noticed. Lift rises, almost linearly, then gently falls and remains constant for values $\alpha \approx 8.5-10^{\circ}$, then the lift force continues to decline slightly, followed by an increase.
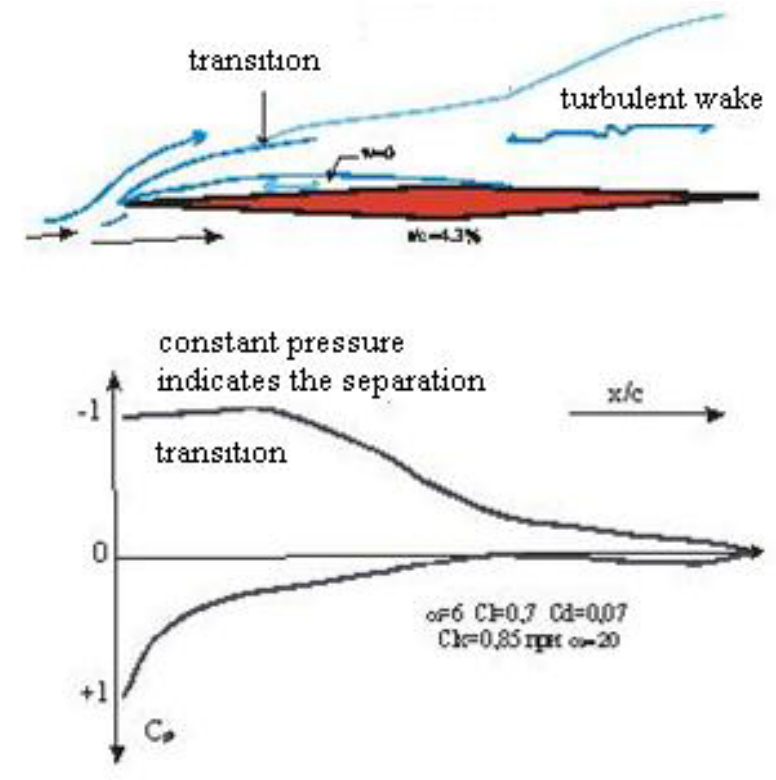

Figure 4 - Example of stalling a thin, sharp airfoil Puc. 4 - Пример сваливания тонкого стреловидногокрыла Slika 4 - Primer prevlačenja tankog, oštrog aeroprofila

The reason for this behavior of airfoils lies in the short distance between the stagnation point (when $\alpha>0$, it is located on the underside) and the leading edge, so that the boundary layer in this zone is very thin.

The Reynolds number is low for the given case.We take into account the existence of a strong negative pressure gradient between the stagnation point (where $\mathrm{C} p=+1$ ) and the leading edge (where probably $\mathrm{Cp}=-10$ ). The airflow over the sharp leading edge is laminar in the boundary layer until abrupt flow separation (McCullough, 1955). Namely, the usual transition to turbulent flow inside the bubble is not typical for this case. After flow separation, as shown in Figure 4, the boundary layer next to a newly formed bubble becomes significant space created by mixing with the fluid within the 
separation bubble. The result of this mixing is the reduced thickness of the separation bubble as the flow moves away from the leading edge to the place where it again joins the boundary layer of the upper airfoil.

The presence of bubbles is recognized through pressure distribution along the airfoil, Figure 4, presenting a constant area of the negative pressure coefficient, where, if the bubble did not exist, there would occur a sudden change in pressure (peak on the curve), which in this case does not exist.

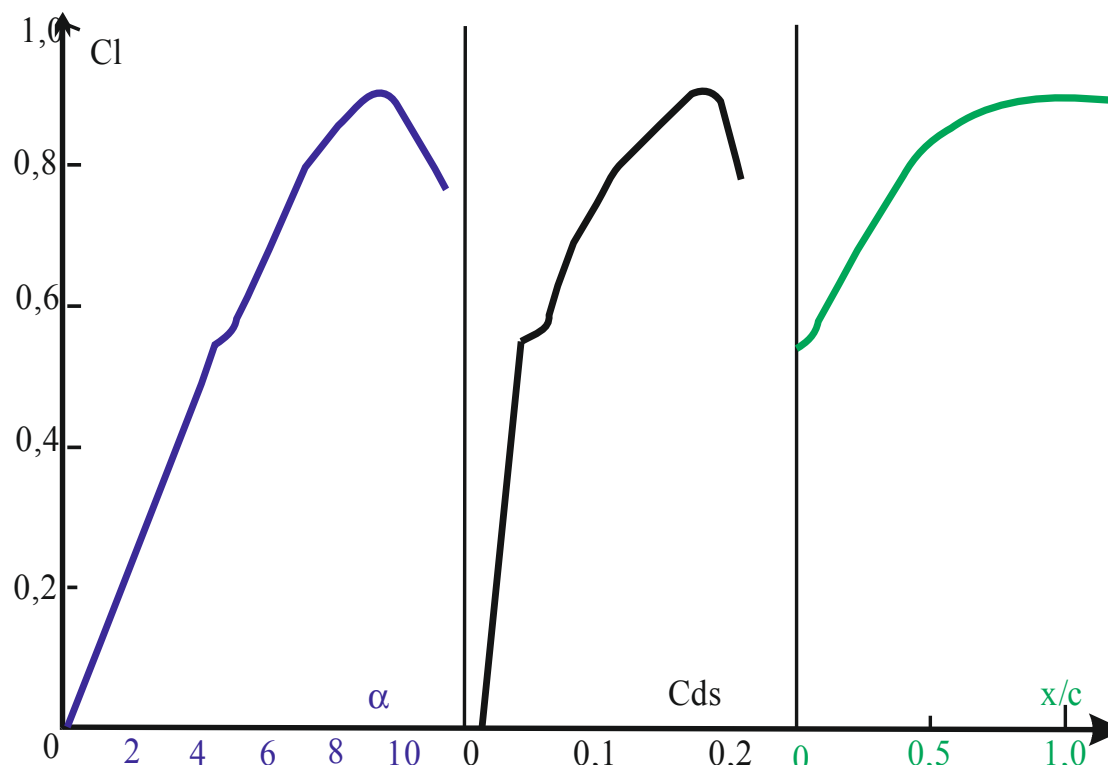

Figure 5 - Lift, drag and the separation bubble characteristic for the NACA 64A006 airfoil a) Lift with discontinuity at $\mathrm{C}_{L}=0.56$

b) Section drag showing sudden increase at $C_{L}=0.56$

c) Length of the separation bubble from the leading edge

Puc. 5 - Подъемная сила, сопротивление и область отрыва

a) Разрыв непрерывности подъемной силы при $\mathrm{C}_{\mathrm{L}}=0,56$

b) Резкий скачок коэффициента сопротивления при $\mathrm{C}_{\mathrm{L}}=0,56$

c) Длина отрывного пузыря упередней кромки

Slika 5 - Uzgon, otpori, separacioni mehur za aeroprofil NACA 64A006

a) Diskontinuitet uzgona pri $\mathrm{C}_{\mathrm{L}}=0,56$

b) Naglo povećanje koeficijenta otpora pri $C_{L}=0,56$

c) Dužina mehura otcepljenja od napadne ivice

In the diagram CL- $\alpha, C D, x / c$ (bubble) for the NACA 64A006 airfoil shown in Figure 5 , it can be noted that in the section $\approx 6 \% \mathrm{x} / \mathrm{c}$ for $\mathrm{CL}=0.56$ acurve discontinuity appears, showing the moment of the creation of initial separation and a bubble, which is reflected in a sudden increase of the drag coefficient.

With a further increase of the angle of attack, the area affected by the separation bubble grows proportionally to a critical moment which 
corresponds to the maximum lift, after which it extends along the entire length of the upper airfoil, followed by the reduction in lift and transit to a stall. In the previous case, the separate bubble extends to $60 \%$ of the airfoil chord $(x / c)$, then the increasing of $\alpha$ leads to the $75 \%$ of the airfoil chord $(x / c)$.

\section{Separation from the leading edge - short bubble shapes}

Short bubble shapes occur as sudden separation when flow passes airfoils with a sharp leading edge, or at flow past a low curved airfoil;

For airfoils characterized by an abrupt onset of a small flow bubble, it is characteristic, as shown in the diagram for the NACA 63-012 airfoil (Figure 3), that the lift force increases almost linearly up to the maximum and then falls sharply.

\section{Separation from the trailing edge}

Separation from the trailing edge is characterized by slight gradual separation. It starts from the trailing edge and moves towards the leading edge, proportionally to the increase of the angle of attack. The NACA 63-018 airfiol, Figure 3, with a rounded leading edge, is a typical representative of the airfoil group in which separation occurs at the trailing edge. It is characterized by an almost linear increase of lift, then a gradual transition to lift loss and complete flow separation. The length at which a separation bubble is formed depends primarily on the airfoil shape. In the case of flow past the airfoil, Figure 4, the length extends up to $60 \%$ of the airfoil chord, while with further increase of the angle of attack separation occurs starting from the airfoil trailing edge. A stall occurs after the moment when the separation begins from the trailing edge and comes to a point of $25 \%$ of the leading edge.

For airfoils used for subsonic flows, the length of the separation bubble varies from $15 \%$ to $25 \%$ of the length of the airfoil chord.

If a rounded leading edge is used, and the airfoil thickness and curvature are increased, the risk of separation bubble formation on the leading edge is eliminated.

The next critical zone for flow separation due to an increased angle of attack is near the trailing edge.

Figure 6 (Pinkerton, 1996) introduces the distribution of pressure along the airfoil at the time immediately prior to reaching the maximum coefficient of lift $\left(C_{L X}\right)$.

The distribution of the pressure coefficient depends on the shape of the airfoil, Reynolds number, angle of attack, relative thickness, curvature of the center line and the relative curvature of the leading airfoil edge. 


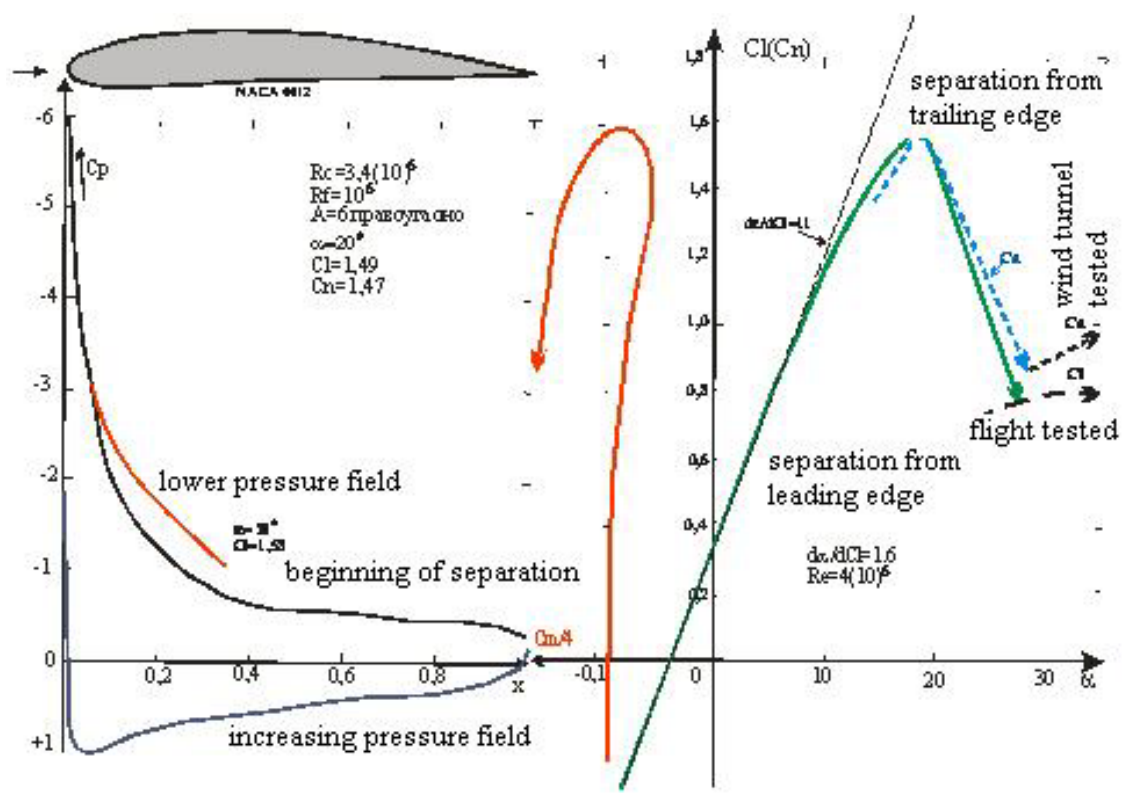

Figure 6-Characteristics of the lift force of the NACA 4412 airfoil and the distribution of $\mathrm{C}_{\mathrm{L}}, \mathrm{C}_{\mathrm{N}}, \mathrm{Cm}$

Puc. 6 - Характеристики подъемной силы профиля крыла NACA 4412 и распределение $\mathrm{C}_{\mathrm{L}}, \mathrm{C}_{\mathrm{N}}, \mathrm{Cm}$

Slika 6 - Karakteristike uzgona aeroprofila NACA 4412 i raspodela $C_{L}, C_{N}, C m$

Let us consider the values of the local maximum speed using the equation:

$$
w / N \approx 1+2 t / c+0.2 C_{L} /(r / t)
$$

where $\mathrm{r} / \mathrm{t}$ is the ratio of the radius of the leading edge and the airfoil thickness (typically between 0.5 and $2.0 \mathrm{t} / \mathrm{c}$ ). A possible maximum local velocity $\mathrm{w}$, the maximum dynamic pressure $\mathrm{q}$ and the minimum pressure coefficient can be obtained from this equation.

Both parts of the right side of equation (3) produce a positive pressure gradient while approaching the trailing edge of the airfoil. Under the influence of this gradient, the boundary layer increases significantly and the trailing edge has a total thickness of $\delta$, which can be written as:

$$
\delta / c=5 C_{f}+k\left(C_{L}\right)^{n}
$$

where $C_{f} \approx 0.03$ is the coefficient of friction resistance, $n=2$, the coefficient $k$ of the order of 10. 
After the boundary layer thickening, it reaches the critical moment when its movement against pressure cannot continue and flow separation occurs in the accumulated boundary layer. As a result, there has been a cessation of circulation increase with the increase of the angle of attack and the lift reaches its maximum.

Figure 6 shows the NACA 4412 airfoil in the $C_{L} C_{m}-\alpha$ diagram. Before reaching its maximum, the lift coefficient diagram diverges from the straight line, initiating flow separation from the trailing edge. An increase of the angle of attack through $C_{L X}$ results in a gradual lift decrease, without discontinuity, down to the angle of attack after which a complete separation flow occurs, which corresponds to the scenario when the separation from the trailing edge is extended to the leading edge.

\section{Airfoils with circular sections}

Let us consider the behavioral characteristics of the lift of the airfoil section with a circular shape, with a curvature of $10 \%$, for three values of the Reynolds number, shown in Figure 7 (Kostić, 2010).

When the airfoil lower sideis flat, the degree of curvature is equal to 0.5 of the airfoil slenderness. The maximum thickness located at $50 \%$ of the length of the chord gives airfoils with the prominent wedge-shaped trailing edge at the site of potential vacum, which easily leads to initial separation. Symmetric thickening with the maximum curvature in the middle of the airfoil, combined on the side with lower pressure, increases sensitivity towards separation flow while approaching the trailing edge.

It can be noticed that, under the sameflow conditions, the behavior of the airfoil depends on the Reynolds number, therefore:

1. When the value of $R e=10^{5}$, the laminar type of separation occurs. The point with the minimum pressure corresponds to the half of the airfoil tendon. Under these conditions, the minimum drag coefficient is 0.02 , which confirms the separation of flow.

2. When the value of $R e=3 \cdot 10^{5}$, at the angle of attack corresponding to the lift coefficient of 0.575 , which is identical to the theoretical $C_{\text {Lsym }}=0.115(f / c) \%$.

The value of the drag coefficient $\left(C_{D S}=0.008=\mathrm{min}\right)$ clearly confirms that this is a completely clean, pressed flow, which represents in this case optimum.

Increasing the Reynolds number over $R e=3 \cdot 10^{5}$ gradually reduces the lift coefficient for a minimum resistance value and for $R e=5 \cdot 10^{6}$ the lift coefficient is $C_{L O}=0.46$. In the separation layer, turbulent flowappears. 

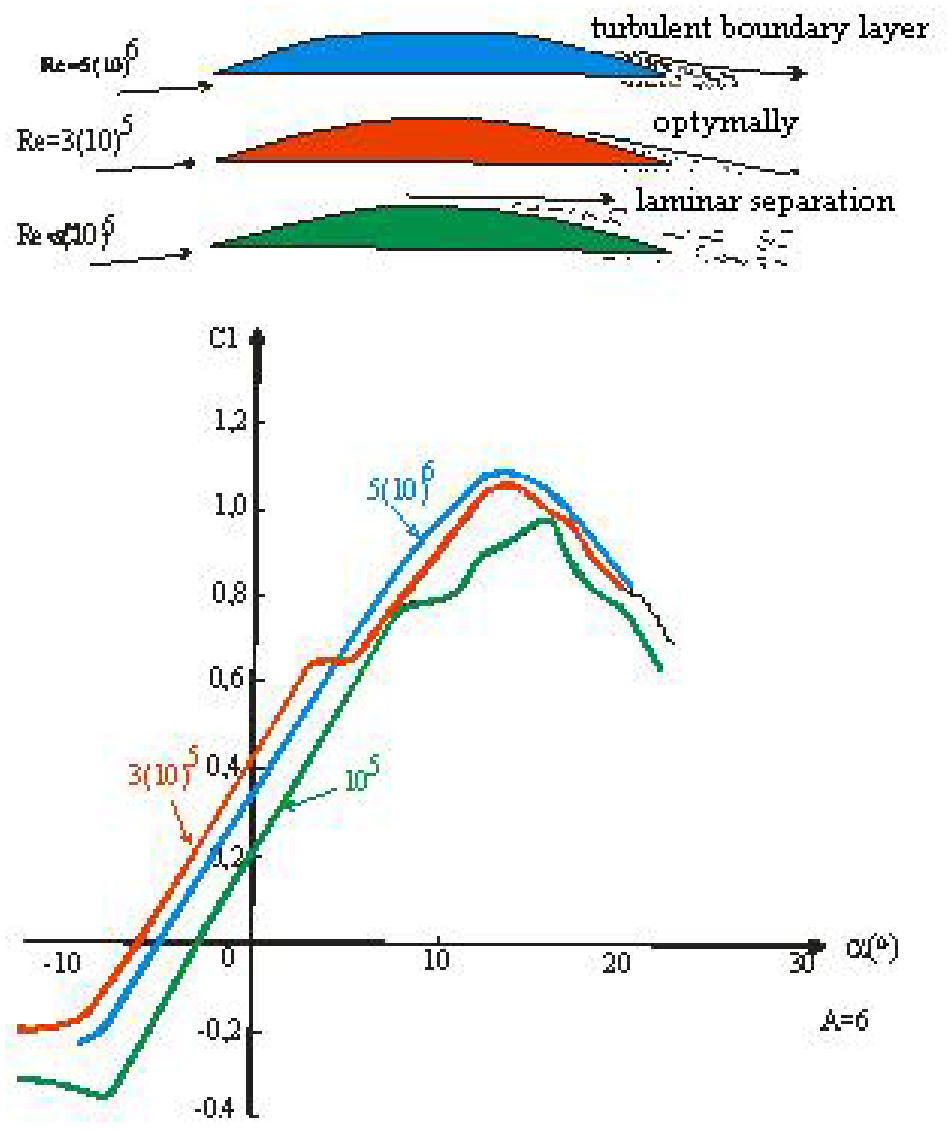

Figure 7 - Characteristics of lift and the mechanism of stalling an airfoil with $10 \%$ of curvature

Puc. 7 - Характеристики подъемной силы и механизм обтекания крыла с $10 \%$-ой кривизной профиля

Slika 7 - Karakteristike uzgona i mehanizam prevlačenja aeroprofila sa $10 \%$ zakrivljenosti

For the observed cases, Figure 7, the graph of the lift coefficient decreases in all three cases. The angle of zero lift at $R e=10^{5} \mathrm{~h}$ as a value of $-3^{0}$; while an increase of the Reynolds number to $R e=3 \cdot 10^{5}$ results in a decrease of the angle of zero liftto the value of $-6^{0}$. However, at the value of $R e=5 \cdot 10^{6}$, the angle of zero lift increases to $-5^{0}$.

This variation of the angle of zero lift value depends on the coefficient of the resistance to friction from the lower value of $10^{5}$ for laminar flow separation, through the part with turbulent separation for which the minimum drag coefficient (optimum) is valid, to the value where turbulent separation is dominant, i.e. a value of $5 \cdot 10^{6}$. 
The curvature of the leading edge of the observed airfoils is possible to reduce the drag coefficient, so the curvature of $r / c \approx 1-2 \%$ gives a reduction in the drag coefficient of $C_{D S}=0.038$ atC ${ }_{D S}=0.017$ for $R e=4 \cdot 10^{6}$.

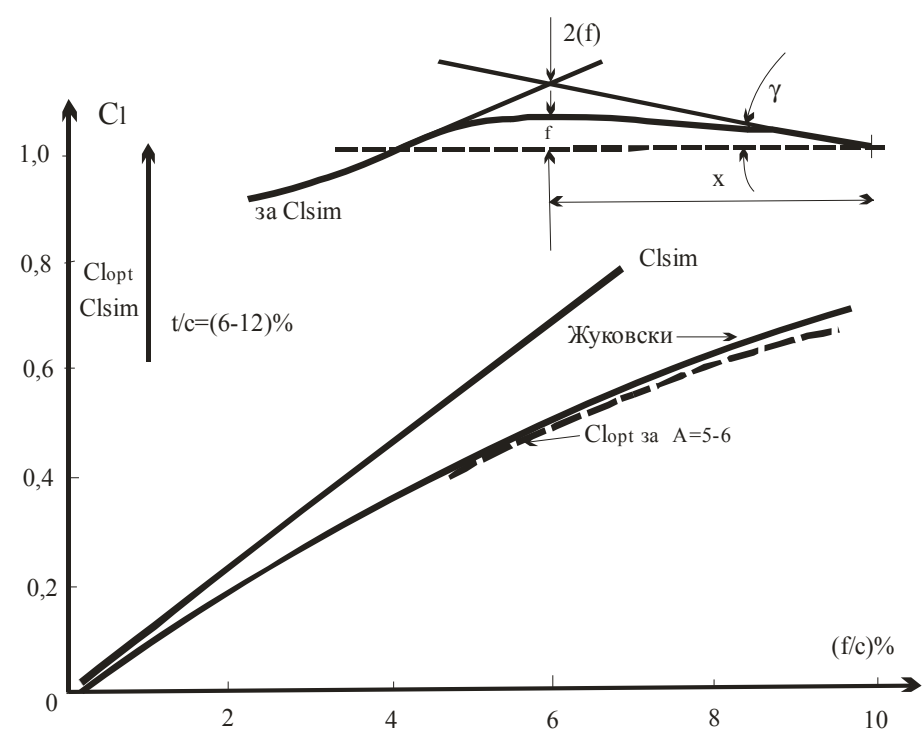

Figure 8 - Optimum lift coefficient as a function of the airfoil camber, $\mathrm{t} / \mathrm{c}=6-12 \%$

Puc. 8 - Оптимальный коэффициент подъемной силы хорды профиля крыла, $\mathrm{t} / \mathrm{c}=6-12 \%$

Slika 8 - Optimalni koeficijenti uzgona u funkciji srednje linije aeroprofila, $t / c=6-12 \%$

The diagram in Figure 8 shows the influence of the airfoil camberand the position of the airfoil maximum thickness to the values of the lift coefficient. The diagram is obtained using the equation $C_{\text {Lsym }}=0.115(f / c) \%$ and compared with the graphs obtained by equations experiments, where it can be concluded that the optimal position of the maximum thickness of subsonic symmetric airfoils is between $30-40 \%$ of the mean airfoil chord.

\section{Maximum lift depending on the shape and $R e$}

Changing the boundary layer and the drag coefficient is directly dependent on the Reynolds number and roughness of the flowsurface. The loss of lift of flow around the body directly depends on the body's shape. The transition from the laminar flow of the boundary layer into the turbulent one can be caused by an external factor (turbulence of the flow field, turbulence inside the wind tunnel, etc.) or by increased surface roughness of the leading airfoiledge. 


\section{$C_{L X}$ as a function of the shape of the leading edge}

Figure 9 shows the dependence of the maximum lift coefficient $\left(C_{L x}\right)$ on the leading edge radius ( $r / c)$ of symmetric airfoils.

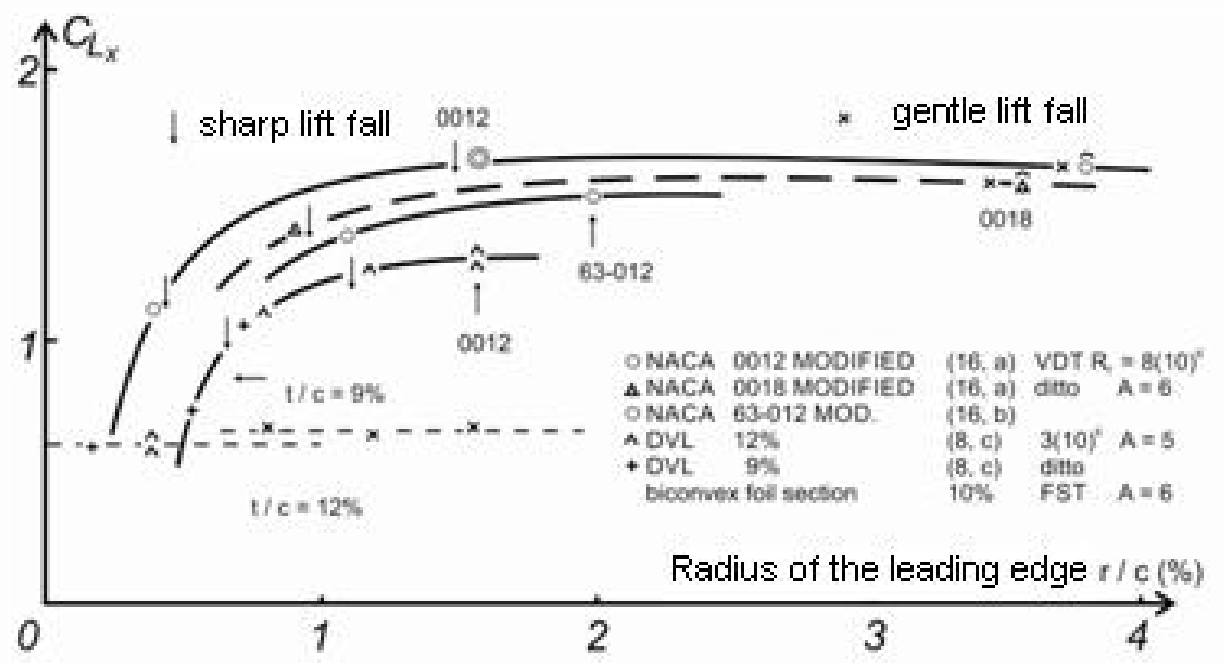

Figure 9 - Maximum lift of symmetric profiles, depending on the leading edge radius $\mathrm{r} / \mathrm{c}$ Puc. 9 - Максимальная подъемная сила симитричного профиля крыла в зависимости от радиуса закругления его передней кромкиг/c

Slika 9 - Maksimalni uzgon simetričnog aerodinamičkog profila, u zavisnosti od radijusa napadne ivice $\mathrm{r} / \mathrm{c}$

The radius which produces the largest lift coefficient is between 1.5 and $2.0 \%$ of the tendon $(r / c=1.5-2.0 \%)$ for the airfoils with $t / c=6-18 \%$.

For NACA 0012, NACA 0018 and NACA 63-012 airfoils shown in Figure 10 (Hoerner, Borst, 1985), it is evident that, with an increase in the $r / c$, the value of $C_{L X}$ grows. From a value of $r / c>1.6 \%$, the gradient of the curve decreases.

It should be considered that, as the curvature of the leading edge of the airfoils increases, the drag coefficient also increases, as shown in Figure 10 (Kostić, 2010), which displays the values of $C_{L}$ and $C_{D}$ for the airfoils of relative thickness of $t / c=6 \%$ and $r / c=0.81 \%$ and $r / c=0.24 \%$ depending on the change in the angle of attack. It is noticeable that the drag coefficient increases as the angle of attack increases.

Airfoils with rounded leading edges have a greater coefficient of lift and a lower drag coefficient at the same angles of attack, so it is only for $\alpha \approx 18^{\circ}$ that the ratio is $C_{L} / C_{D}<1$. 


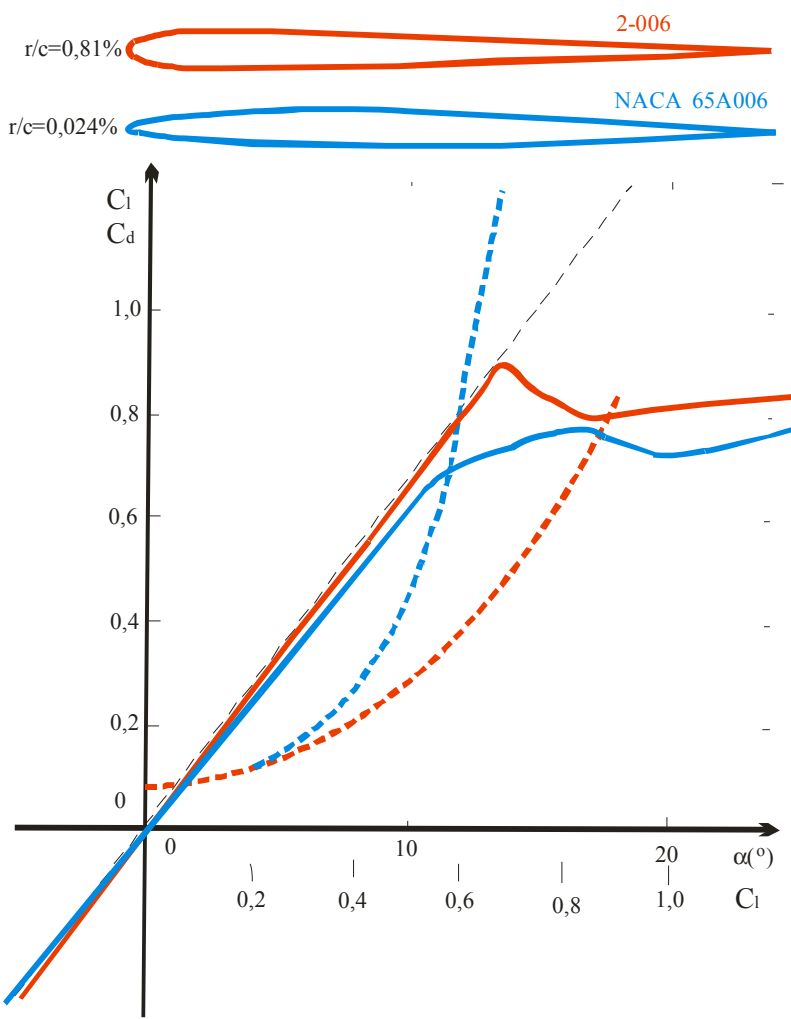

Figure $10-$ Lift and drag $\mathrm{t} / \mathrm{c}=6 \%$ of airfoilswith different leading edges, $\operatorname{Re}=5 \cdot 10^{5}$ Puc. 10 - Подъемная сила и сопротивление $\mathrm{t} / \mathrm{c}=6 \%$ профиля крыла с различными передними кромками, $\operatorname{Re}=5 \cdot 10^{5}$

Slika 10 - Uzgon i otpor $\mathrm{t} / \mathrm{c}=6 \%$ aeroprofila različitih napadnih ivica, $\mathrm{Re}=5 \cdot 10^{5}$

It is noticeable that the values of the $C_{D \min }$ are of approximately same values, and that flow separation at lower values of the angle of attack has resulted in a rapid increase of the drag coefficient for the airfoil with a sharper leading edge.

The mechanism of separation of flow around a thin airfoil can be considered the same as the one in airfoils with sharp leading edges, especially for the values of $\operatorname{Re}<10^{5}$ (von Karman, 2001).

Figure 11 shows the dependence of the curvature of the leading edge of the airfoil $(r / c)$ and $R e$. It can be seen that the methods of flow separation can be grouped depending on the values $(r / c)$ and $R e$. For the curvature of the leading edge from $0.25 \%$ to $1.60 \%$, it can be concluded that, at $\operatorname{Re}<10^{6}$, separation flow corresponds to the model of thin airfoil separation, while for $R e>2 \cdot 10^{6}$ separation flow corresponds to the model of thin airfoil separation and trailing edge separation. 


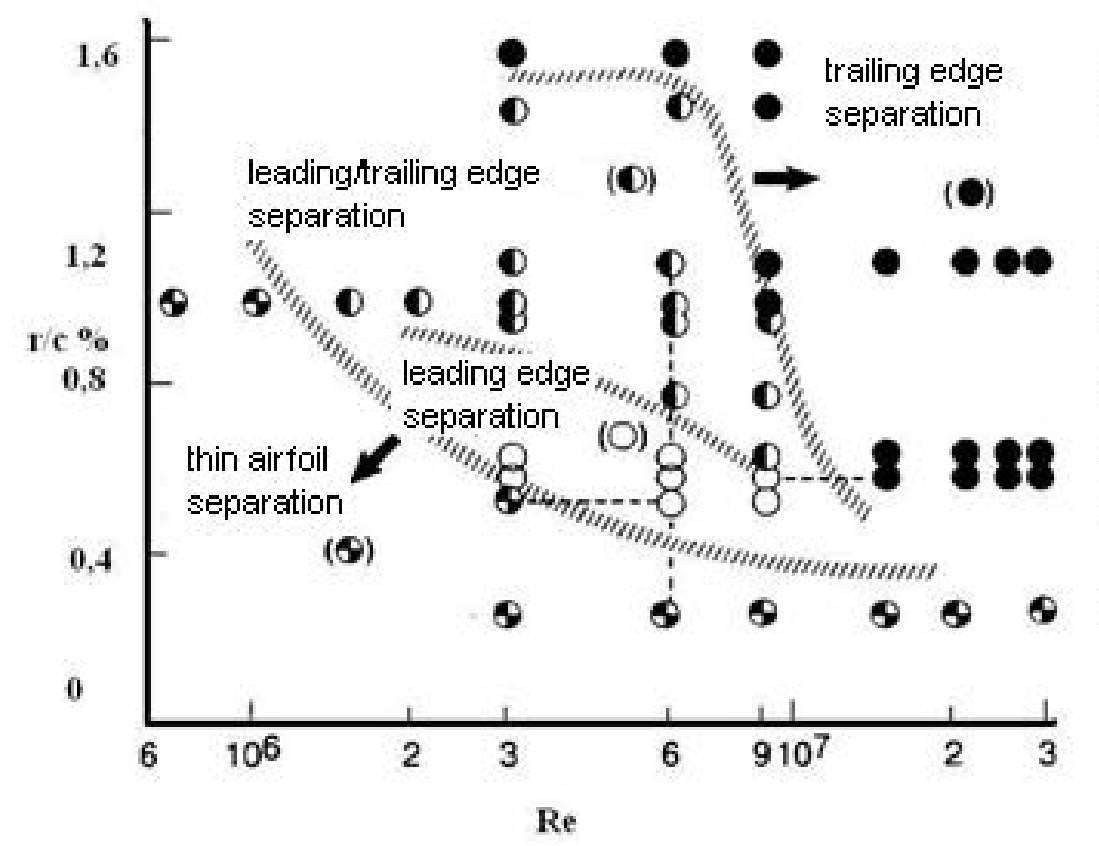

63-012

$64-012$

63.010

63-009

64-009

$65-009$

$64-006$

Figure 11 - Stall domains due to the leading edge radius $\mathrm{r} / \mathrm{c}$ and $\mathrm{Re}$

Puc. 11 - Модель срыва потока в зависимости от закругленности передней кромки $\mathrm{r} / \mathrm{c} \mathrm{и} \mathrm{значения} \mathrm{Re}$

Slika 11 - Model otcepljenja strujanja u zavisnosti od zaobljenosti napadne ivice r/c i vrednosti Re

A typical example of application of sharp leading edges is seen when creating ship propellers, where the value of the Reynolds number is below the critical value of $\operatorname{Re}<10^{5}$.

\section{The curvature of the airfoil leading edge sectors}

Also, $C_{L X}$ is a function of the curvature of the airfoil leading edge sector (camber line of the airfoil), $f / c$, and the shape of the leading edge, i.e. $r / c$. Around the thin airfoil leading edge, a flat plate, flow bends from the lower side through the leading edge to the upper side. At larger Reynolds numbers, laminar separation and the bubble effect of the boundary layer can be reduced.

Figure 12 shows the change in the lift coefficient of airfoils with sharp leading edges for different values of the curvature of the center line of the airfoil in the conditions of flow of similar Reynolds numbers. 


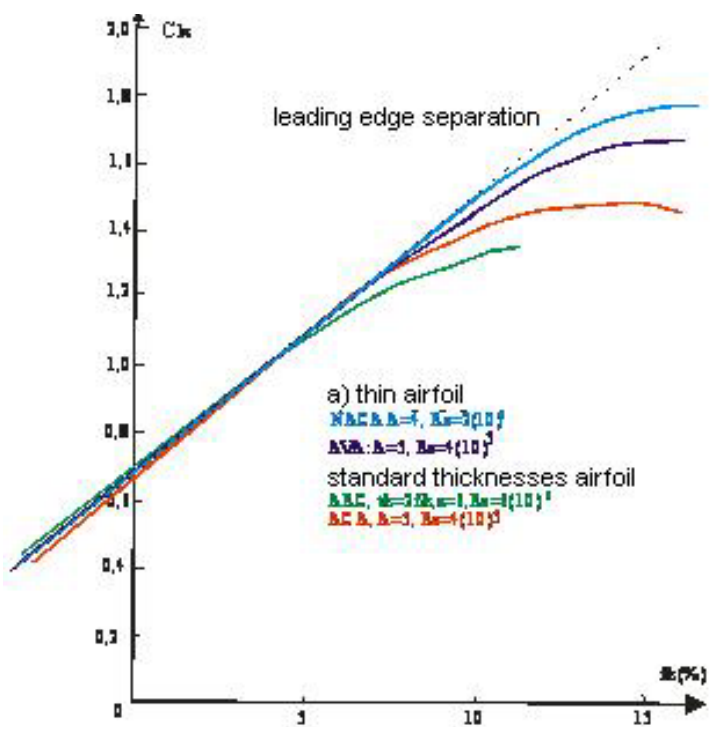

Figure 12 - The maximum lift coefficient of an airfoil with a sharp leading edge, as a function of the degree of curvature of the camber line of the airfoil

Puc. 12 - Максимальный коэффициент подъемной силы крыла с острой передней кромкой, как функция степени округленности средней линии профиля

Slika 12 - Maksimalni koeficijent uzgona aeroprofila oštre napadne ivice, kao funkcija stepena zakrivljenosti srednje linije aeroprofila

It can be said that there is no difference in the examples shown in terms of the location of the maximum curvature of the camber line of the airfoil for the maximum lift between $30 \%$ and $50 \%$ of the chords of the airfoil. This is illustrated by graphically presenting the $C_{L X} /(f / c)$ relations, obtained by testing airfoils in the wind tunnel, (Doenhoff, 2015) Figure 13.

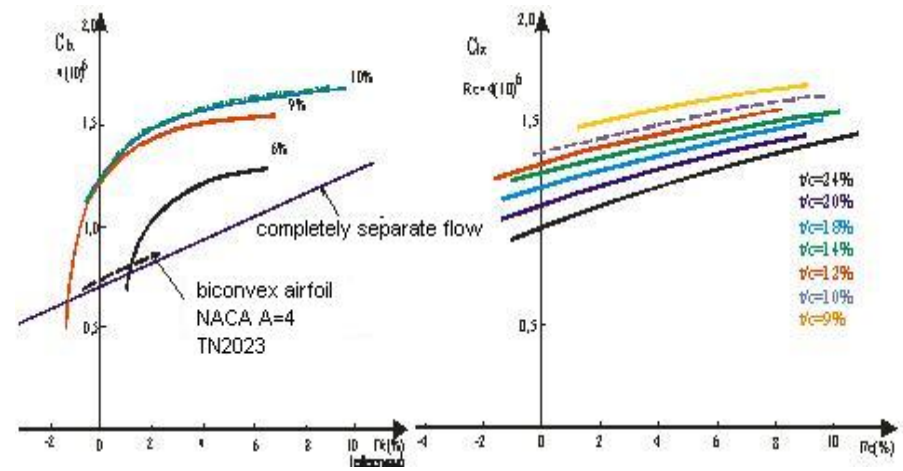

Figure 13 - The maximum lift coefficient, relative maximum lift coefficient, the relative thickness of airfoil $6-9 \%$ and $12-24 \%$ for $R e, f=4 \cdot 10^{6}$

Puc. 13 - Максимальная подъемная сила, относительный максимальный коэфрфициент относительной толщины профиля6-9\% и $12-24 \%$, для $\mathrm{Re}, \mathrm{f}=4 \cdot 10^{6}$

Slika 13 - Maksimalni koeficijent uzgona, relativni maksimalni koeficijent uzgona, relativne debljine aeroprofila $6-9 \%$ i $12-24 \%$, za $\operatorname{Re}, f=4 \cdot 10^{6}$ 
After the adjustment to $A=5$ in accordance with the equation (Kostić, 2010):

$$
(f / C) \% \approx(1.4+0.2) C_{L}=1.6 \% C_{L}
$$

the characteristics of thin airfoils, with $t / c=6$ and $9 \%$, are shown in Figure 13 , which shows that, for the degree of curvature of the camber line of the airfoil between $-1 \%$ and +1 , the maximum lift coefficient corresponds to the critical angle of attack of separation flow (of $30^{\circ}$ ).

Practical use of thin airfoils and the curvature of sections in aviation is limited by structural conditions (providing the necessary wing capacity for the required airfoil thickness), but they are applicable in the construction of turbine blades and fan blades.

The coefficients of the maximum lift decrease with the increase of the maximum relative thickness of airfoils of $12 \%$ or more are shown in Figure 13. The maximum lift coefficients grow as a function of a relative airfoil curvature, to the airfoils with the highest tested curvatures, those of $10 \%$.

The study of the NACA 63012 airfoil, Figure 14, at $R e=5(10)^{6}$ and $M=0.18$, leads to the conclusion that at $C_{L x}=1.36$ separation flow occurs suddenly, with strong shocks and shaking for angles corresponding to the values immediately prior to the occurrence of separation. This can also be anticipated by observing the diagram in Figure 8.

Increasing the radius of the leading edge nose of $1.1 \%$ to $2 \%$ of the length of the camber aerodynamic chord, makes $C_{L x}$ grow to a value of 1.50 , while a sudden stall is still present.

To avoid a sudden stall, the airfoil leading section was folded, Figure 14. The values of $C_{L x}$ grow again, but a sudden stall is still present. Separation occurs following the model of a thin airfoil with a separation bubble which does not change from the initial shape to the moment when it suddenly increases and extends towards the trailing edge. The distribution of the pressure coefficient shows that separation occurs at $C_{p \min }=-10$. 


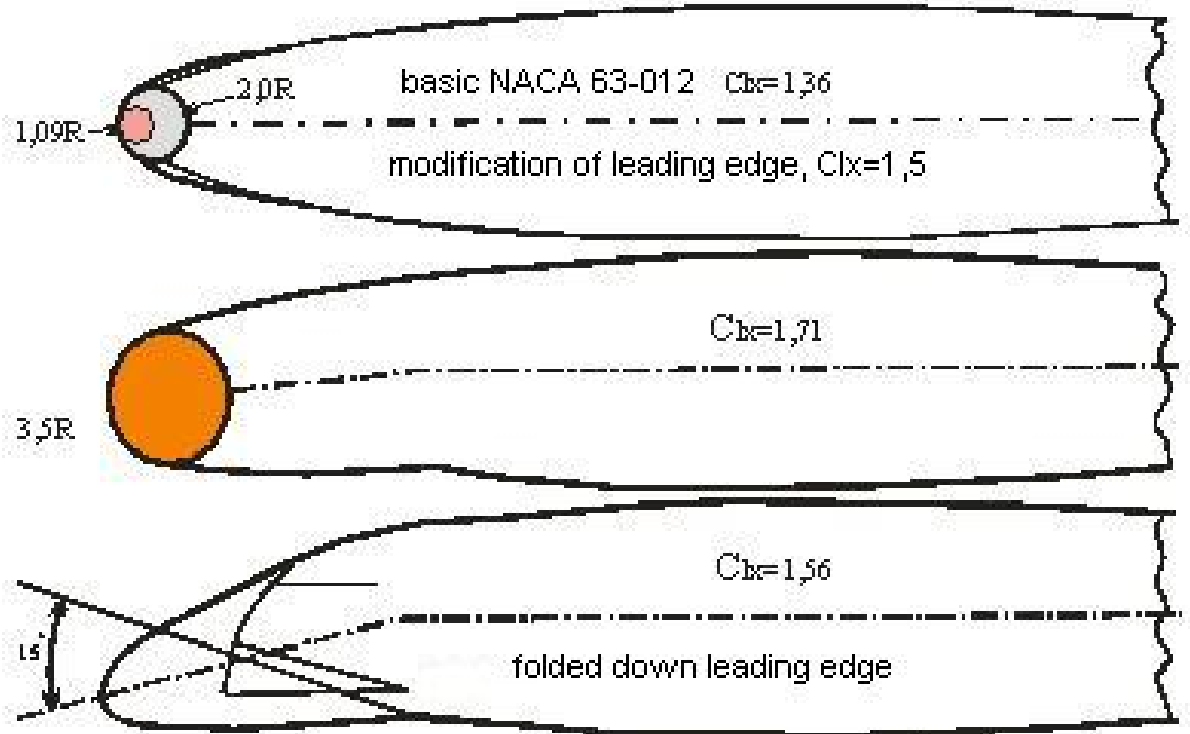

Figure $14-$ Modifications to the leading edge, NACA 63-012, $\operatorname{Re}=4.9 \cdot 10^{6}$ Puc. 14 - Модификация передней кромки, NACA 63-012, $\operatorname{Re}=4,9 \cdot 10^{6}$ Slika 14 - Modifikacije napadne ivice, NACA 63-012, $R e=4,9 \cdot 10^{6}$

Changing the curvature and the radius of the airfoil leading edge increases the value of the maximum lift approximately, but it does not change the separation mechanism. As a sudden entry intoa stall is unfavorable, it is recommended that a combination of the relative thickness and the airfoil curvature is used to transfer the mechanism of sudden separation occurrence in the attack sector to gradual separation which is a characteristic of the separation from the trailing edge.

\section{The critical Reynolds number}

When choosing airfoils (any aerodynamic form), it is important to know the values of the Reynolds number for which they can be used. The critical Reynolds number at which turbulent flow occurs in the boundary flow field of the upper wing surface for thin airfoils is $R e=10^{5}$, Figure 15 (Kostić, 2010). It is noticeable that airfoils with a smaller curvature have higher values of the critical Rewith an increase in $C_{L X}$. 


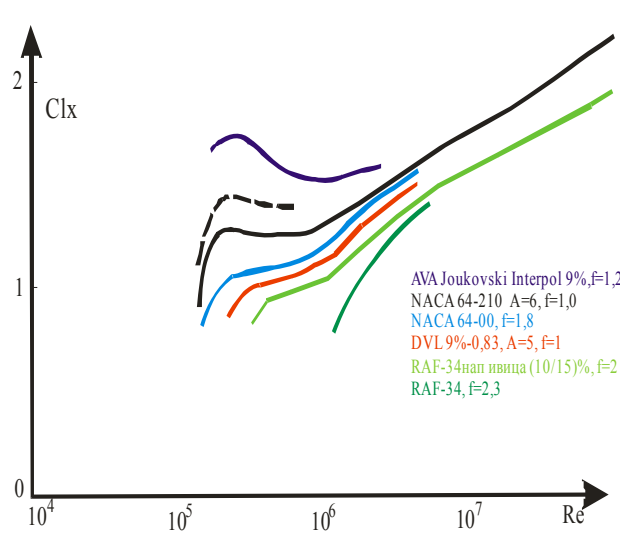

Figure 15 - Maximum lift of rectangular wings as a function of $\operatorname{Re}, t / c=8-10 \%$

Puc. 15 - Максимальная подъемная сила правоугольного крыла как функция $\mathrm{Re}$, $\mathrm{t} / \mathrm{c}=8-10 \%$

Slika 15 - Maksimalni uzgon pravougaonih krila kao funkcija Re, $\mathrm{t} / \mathrm{c}=8-10 \%$

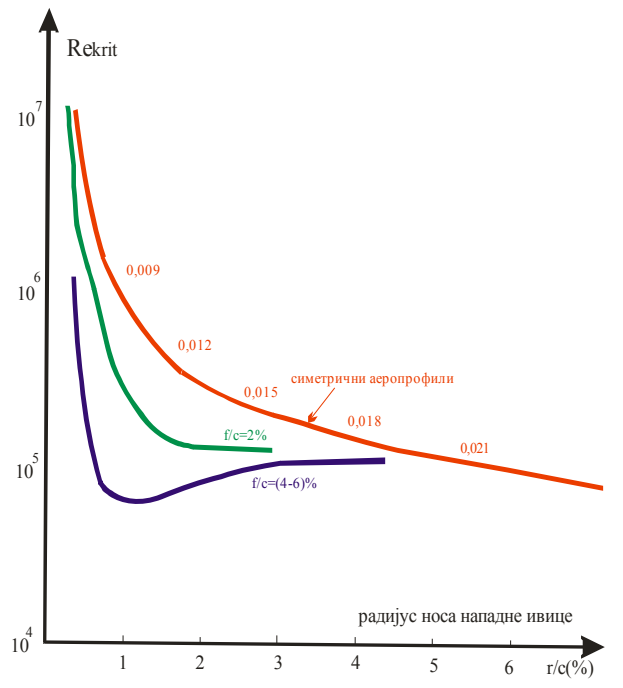

Figure 16 - Critical Re as a function of the radius at the leading edge of the airfoil

Puc. 16 - Критический $\mathrm{Re}$, как функция радиуса закругления передней кромки Slika 16 - Kritični Re, kao funkcija radijusa napadne ivice

Airfoils such as the NACA 0009 have the same critical way of changing the image of the flow at higher values of $\mathrm{Re}$. The transition from laminar to turbulent flow occurs at ten times higher values of $R e$ than in airfoils with higher relative thickness and the radius of the leading edge.

The radius of the leading edge with the increase decreases the values of the critical Re, as shown in Figure 16 (von Karman, 2001). Airfoils with smaller curvature have a higher value ofthe critical Re with an increase in $C_{L X}$. For larger Reynolds numbers $\left(10^{6}\right.$ to $\left.10^{7}\right)$, they represent aircraft at low speed during landing and takeoff. The $C_{L X}$ values are shown in the diagrams above.

The characteristics of airfoils for Reynolds numbers in this range are:

- Flat planes and airfoils with thickness up to $3 \%$ have the same approximate maximum lift coefficient, with separation characteristic for thin airfoils;

- Thin airfoils $(t / c=5-10 \%)$ are characterized by increasing $C_{L X}$ as their camber line curvature increases from $0 \%$ to $2 \%$ (Figure 16). Loss of lift varies from sudden to gradual, depending on the shape and dimensions of the airfoil and on flow past an airfoil conditions; 
As it can be seen in Figures 16 and 17, airfoils with a relative thickness between 8 and $12 \%$ and the curvature of the camber line between $0 \%$ and $2 \%$ have a strong tendency towards increasing the maximum lift. Increasing the angle of attack leads to the characteristic flow around the leading edge and to a gentle transition from laminar to turbulent flow.

For airfoils with larger curvature and with aprominently rounded leading edge, flow continues around the leading edge, while the maximum lift coefficient is in a function of the angle of attack at which the laminar boundary layer extends towards the trailing edge. $C_{L X}$ depends on the coefficient of friction along the profile of the upper side of the airfoil. For Reynolds numbers whose value exceeds $10^{7}$, the drag coefficient increases as a result of an increase in the thickness of the boundary layer.

It is noticeable that, depending on the tendencies of $C_{L X}$ change, different types of separation flow occur:

- Airfoils with separation flow of the thin airfoil type are characterized by a fairly constant value of the maximum lift coefficient;

- Airfoils with rapid separation flow tend to increase $C_{L X}$ with an increase of the Reynolds number;

- Airfoils in which the separation bubble is formed towards the airfoil trailing edge with increasing $\mathrm{Re}$ grows slowly, so that the maximum lift coefficient decreases for cases with larger curvature of the camber line.

\section{Theoretical analysis}

In the early theoretical studies of the boundary layer around the leading edge of the airfoil, the maximum lift was analyzed as a function of the Reynolds number and turbulence flow for thin and curved airfoils. The theory was applicable for Reynolds numbers at which there occurs separation flow characteristic for separation in the leading edge characterized by a laminar separation bubble.

For the case where separation is in relation to the trailing edge, the maximum lift coefficient is the result of the balance between kinetic and pressure forces. Potential energy is represented by an increase in pressure between the point of minimum pressure and the trailing edge. For sections with a pronounced curvature and a rounded leading edge, separation can be determined as a function of the kinetic energy inside the boundary layer. Therefore, while the kinetic energy inside the boundary layer is a function of the Reynolds number and grows in line with the decline in the value of the frictional drag, it can be said that:

$$
C_{L X} \approx 1 / \sqrt{C_{f}} R_{e} \sim R_{e}{ }^{n}
$$

where $n=0.5(1 / 6)=1 / 12$ and $1 / 6$ is the equivalent ratio during turbulent flow. On the basis of the aforementioned, the above equation can be applied to the value of $R_{e}<10^{7}$. 


\section{The relative thickness of airfoils}

For Reynolds numbers of $4(10)^{6}$,Figure 17 shows the dependence of the maximum lift coefficient and the relative thickness of the airfoil.

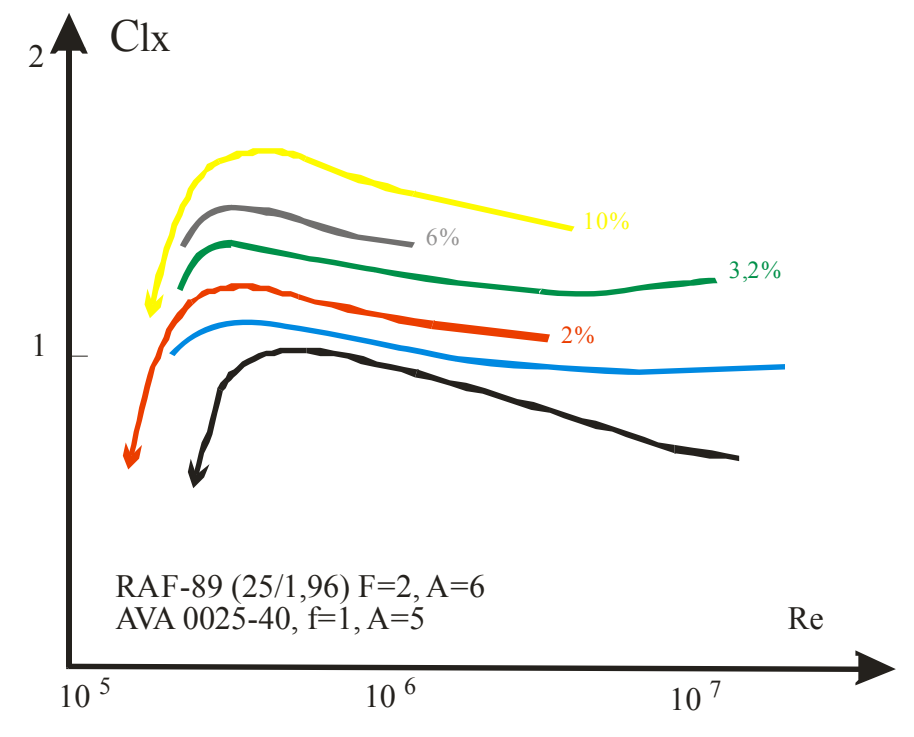

Figure 17 - Airfoil maximum lift, as a function of $\mathrm{t} / \mathrm{c}$, at $\mathrm{Re}=4 \cdot 10^{6}$

Puc. 17 - Максимальная подъемная сила крыла, как функция $\mathrm{t} / \mathrm{c}$, при $\operatorname{Re}=4 \cdot 10^{6}$

Slika 17 - Maksimalni uzgon aeroprofila, kao funkcija t/c, pri Re $=4 \cdot 10^{6}$

The maximum lift coefficient is rising sharply in line with the relative curvature of the camber line of the airfoil between $0 \%$ and $2 \%$, and for the relative thickness of $t / c=5-8 \%$. For values of $t /$ cover $8 \%$ and $f / c o v e r$ $4 \%$, the airfoilis characterized by stalling as in thin airfoil. The peaks of the curves can be obtained for values $t / c \approx 10 \%$. The source in literature stated that during the experiment, for the values of $t / c=12 \%$, airfoils showed more efficiency, especially at high subsonic speeds.

Airfoils with $t / c=(0$ до 10)\% are most common, and thus most tested, representing a compromise between the aerodynamic and structural demands of an object in an air stream.

Depending on structural needs, the relative thickness of airfoils increases; consequently, the value of $t / c \approx 18 \%$ is characteristic for the root of the wing of subsonic aircraft. Over the value of $t / c=18 \%$, the maximum lift coefficient gradually declines; therefore, a stall is gradual and predictable. 


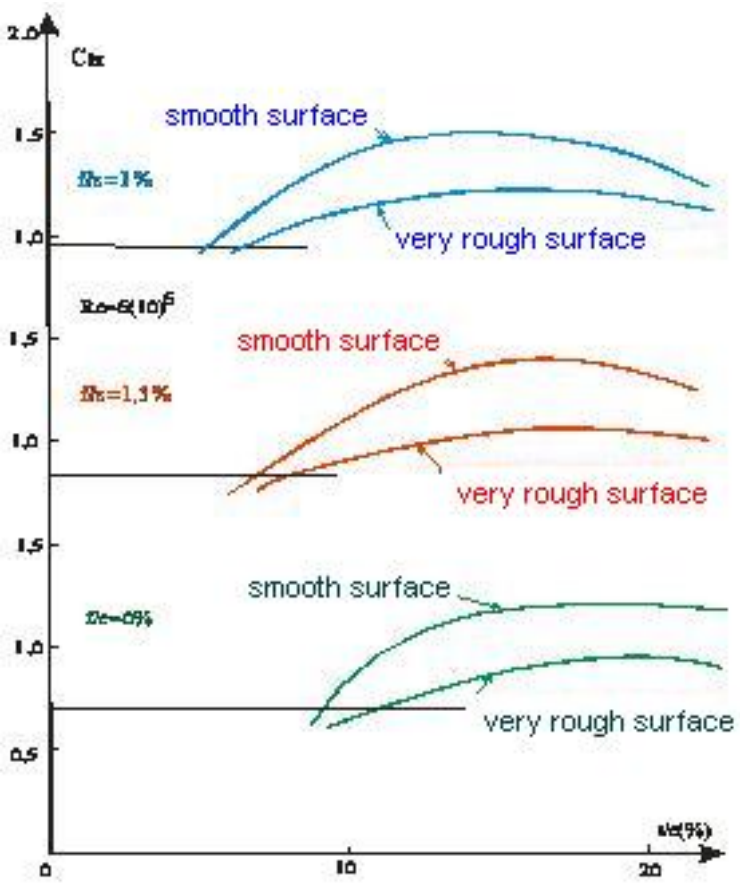

Figure 18 - Maximum lift of airfoils of series 63 and $64, R e=6 \cdot 10^{6}$,

as a function of the relative thickness and curvature of the airfoil, for $A=5-6$

Puc. 18 - Максимальная подъемная сила крыла серии 63 и $64, \operatorname{Re}=6 \cdot 10^{6}$

как функция толщины аэродинамического профиля и кривизны хорды, для A= 5-6

Slika 18 - Maksimalni uzgon aeroprofila serija 63 i $64, \operatorname{Re}=6 \cdot 10^{6}$, kao funkcija relativne

debljine aeroprofila i zakrivljenosti srednje aerodinamičke tetive, za $A=5-6$

\section{High-speed airfoils}

Increasing the relative thickness of the airfoil and increasing the camber line lead to the increase of the torque of the resulting aerodynamic forces; therefore, a special attention is given to airfoil sections exposed to high speeds.

The position of the maximum camber is not that important for the maximum lift value, it is important that it is between 0.30 and 0.50 of the aerodynamic chord. On the other hand, the position of the maximum thickness has a significant impact, especially if the radius of the leading edge changes at the same time.

Figure 18 indicates the relation between the maximum lift coefficient and the relative thickness of the airfoils of the NACA airfoil series 63 and 64 and $\operatorname{Re}=6(10)^{6}$. 


\section{The influence of surface roughness}

In theoretical studies of aerodynamic characteristics of an object in an air stream, the object surface is taken to be absolutely smooth. However, in real conditions, there is not an absolutely smooth surface. The following examples will show how uneven airfoil skin influences the occurrence of separation flow, i.e. the value of the maximum lift.

Increasing the roughness of the upper side leads to increased lift for a given angle of attack. On the other hand, increasing the roughness of the lower side reduces the lift for a given angle of attack. The increase of roughness directly affects the thickness of the boundary layer, as well as the flow in it.

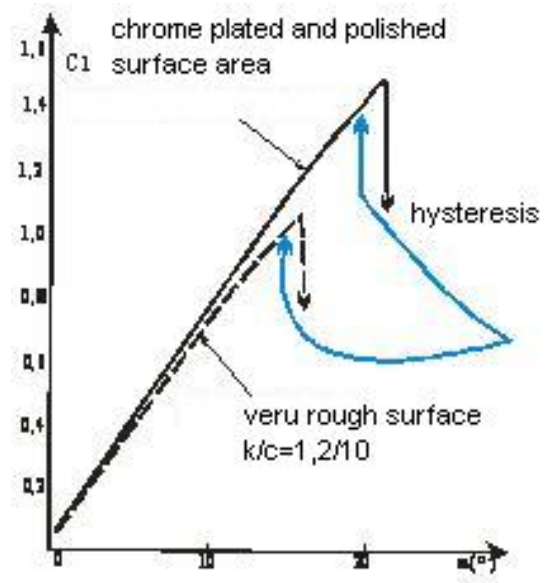

Figure 19 - Airfoillift, $A=6, R=6 \cdot 10^{6}$ for smooth and rough surfaces

Puc. 19 - Подъемная сила крыла, $A=6, R=6 \cdot 10^{6}$ для гладкой и шероховатойповерхностикрыла

Slika 19 - Uzgon aeroprofila, $A=6, R=6 \cdot 10^{6}$ za glatke i hrapave površine

Figure 19 shows an $C_{L} / \alpha$ diagram of the airfoil observed under the same conditions, but with a different state of skin. It is clear that, with increasing roughness of the skin, the maximum value of the lift coefficient reduces together with a slight decrease of the lift gradient. It is noticeable that in this case airfoils behave similary after the decline of lift.

In real conditions, roughness is caused by aircraft production technologies and as such can be controlled and avoided on desired surfaces. During flight, there is damage to aerodynamic surfaces (to a lesser extent due to sand or insects and to a a greater extentdue to impacts of birds, which can lead to significant changes in the airfoil geometry). 
A special case is the appearance of ice on leading edges, as a result of specific meteorological conditions of flight. Figure 20 shows the results of flow past the NACA 2212 airfoil, at $R e=4(10)^{4}$, with and without the effect of ice (Kostić, 2010).
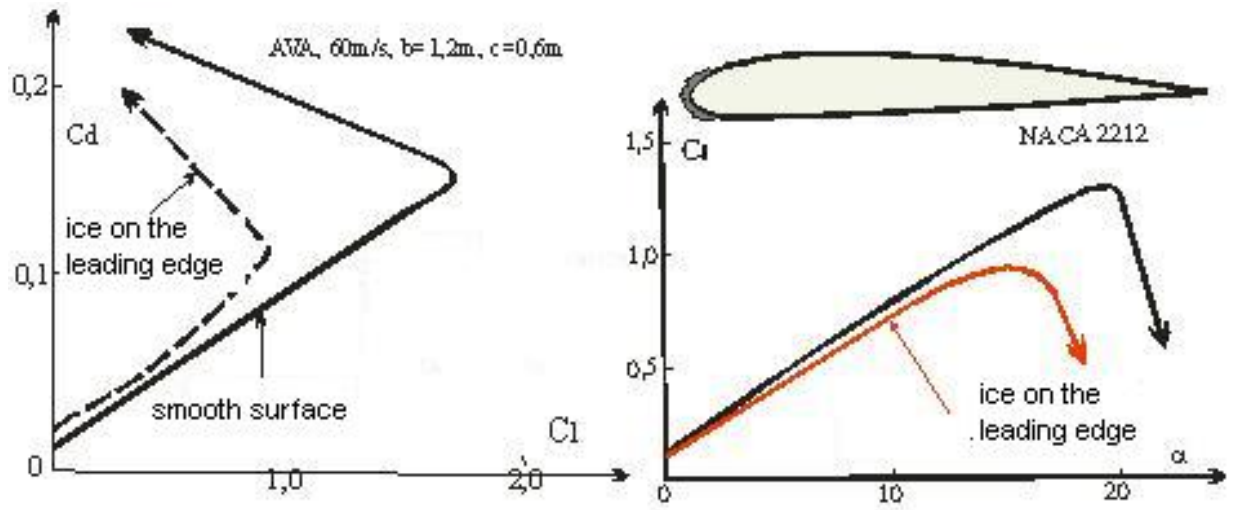

Figure $20-C_{L}, C_{D}$ with and without simulation of ice on the leading edge of the NACA 2212 airfoil

Puc. $20-\mathrm{C}_{\mathrm{L}}, \mathrm{C}_{\mathrm{D}}$ C и без симуляции льда на передней кромке крыла NACA 2212

Slika $20-C_{L}, C_{D}$ sa i bez simulacije leda na napadnoj ivici za aeroprofil NACA 2212

Ice on the leading edge of the airfoil significantly reduces the value $C_{L \max }$ from 1.3 to 1.0; it increases the coefficient of resistance due to the increased turbulence of the boundary layer and increases the frictional drag.

In addition to the changes of the final values of the $C_{L}$ and $C_{D}$, there are changes of their functions as well. The $C_{D} / C_{L}^{2}$ ratio is affected, causing directly a change in the position of the aerodynamic center forward, which in flight requires an additional deflection of the rudder height, and thus a change of the angle of attack, which further complicates the problem of the spread of ice-affected areas.

\section{The aerodynamic characteristics of the airfoil after stalling}

Reaching the maximum lift with a further increase in the angle of attack leads to a faster or slower lift decline (depending on the observed flow past airfoils and its conditions). When the pitch-stall, or when a propeller pitch is increased, and also when there is a need for a reversible propeller pitch, the angle of attack increases.

In Figure 21, the behavior of the airfoil for given conditions of $\alpha=0^{\circ}$ up to $\alpha=180^{\circ}$ is shown (Critzos, 1985). 


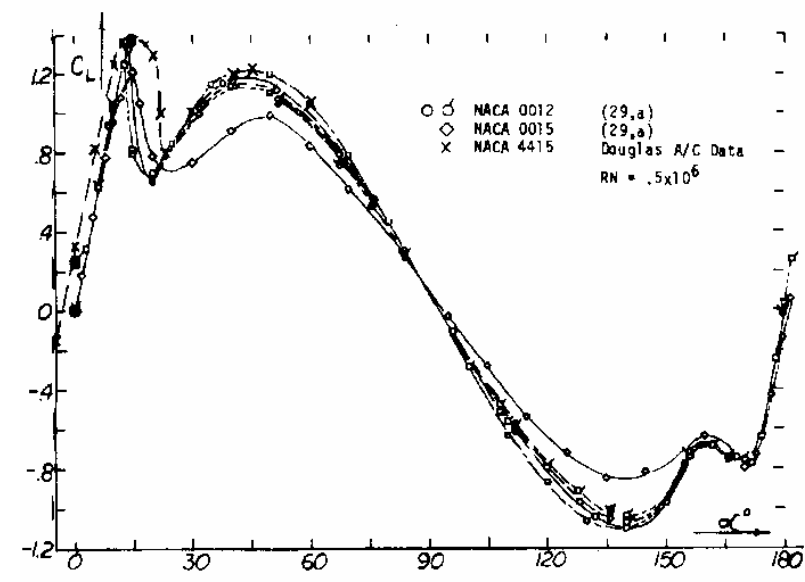

Figure 21 - Variations of the lift coefficient for $\alpha=0^{\circ}-180^{\circ}$

Puc. 21 - Вариации значений коэффициента подъемной силы при $\alpha=0^{\circ}-180^{\circ}$ Slika 21 - Varijacije koeficijenta uzgona za $\alpha=0^{\circ}-180^{\circ}$

The value of the airfoil lift coefficient is similar, but it can be seen that:

- After separation, the resultant force is approximately perpendicular to the chord;

- Lift force reaches the second maximum at $\alpha \approx 45^{\circ}\left(C_{D} \approx 1.0\right)$ so that the normal force is $C_{N} \approx \sqrt{ } 2=1.43$.

- When $\alpha=90^{\circ}, C_{L} \approx 0$ and $C_{D} \approx 1.8$, which is close to the value of the drag for a flat plate of the same angle of attack $\left(C_{D} \approx 1.95\right)$;

- For the value of the angle of attack between $90^{\circ}$ and $180^{\circ}$, it is characteristic that the sharp trailing edge has become a leading one, and the rounded leading edge has become a trailing edge, which is characterized by increased lift and reduced drag, but with different values and similar behavior.

\section{Influence of the dynamics of the stall}

In the previous analyzes of a stall, we started from the assumption that the change of the angle of attackis is gradual, so that we have considered stationary flow. But in real conditions of exploitation, changes of the angle of attack do not correspond to this assumption, especially if working conditions of helicopter rotors are taken into account, or parts of wing machinery during sudden maneuvers.

Figure 22 illustrates the changes in the lift coefficientat gradual and sudden changes in the angle of attack (Kostić, 2010). 


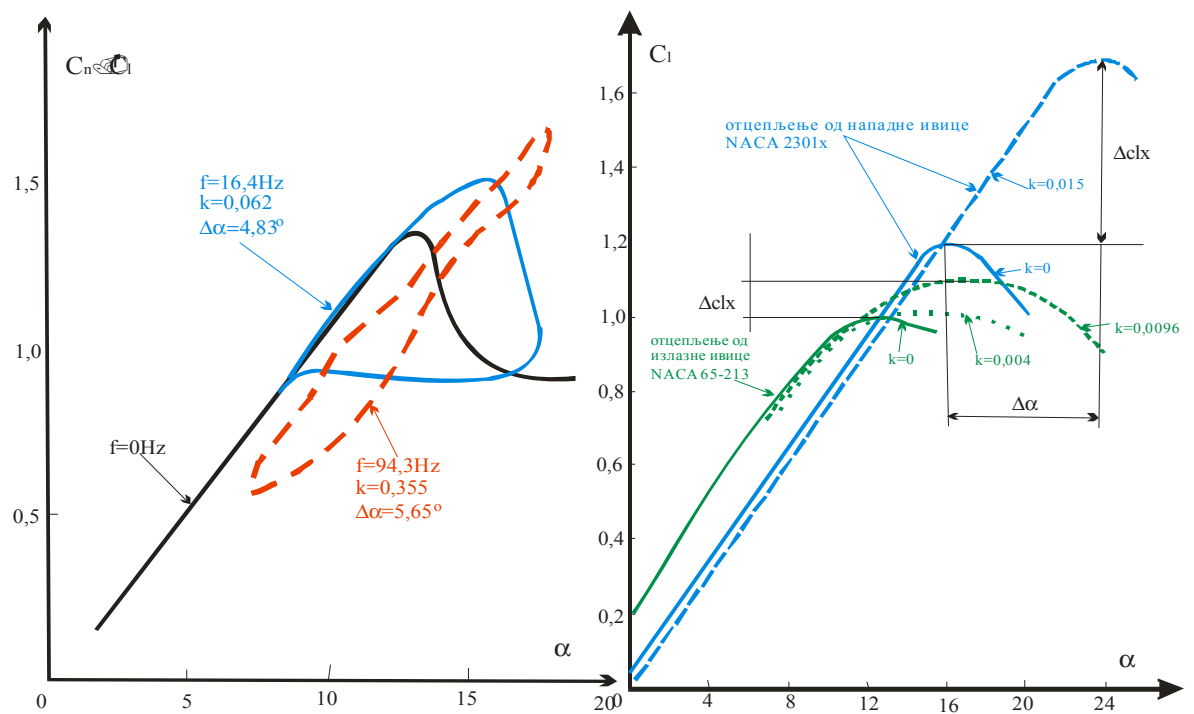

Figure 22 - Dynamic effects of changes in $C L-\alpha(t)$

Puc. 22 - Динамические эфффекты изменений CL-a(t)

Slika 22 - Dinamički efekat promena CL-a(t)

It is noticeable that a sudden increase in the angle of attack leads to a short-term lift increase. Keeping the angle of attack leads to a uniform flow past the airfoil, which leads to a stall.

A sudden increase in the angle of attack followed by return to its initial value shows that the value of the lift coefficient reduces compared to the stationary change of the angle of attack.

The diagram CL- $\alpha$ depends on the mode of airfoil entry into a stall. The cases of separation characteristic for the trailing edge have a more rounded shape of the curve than separation cases that occur at the leading edge.

The reduced frequency of changes of the angle of attack is $k=c \omega / V$, where $c$ is the chord line, $\omega$ is frequency of changes of the angle of attack, and $V$ represents velocity.

This equation is valid for non-compressible flow. For compressible flow, it is written as: $k=c \omega / V_{0}(1-M)^{1 / 2}$.

\section{Conclusion}

The selection of an aerodynamic shape of an object in an air stream is a complex task. It is in relation to the conditions and purpose of flow past an objectas the starting factors. One of the limiting factors in exploitation is turbulence. 
The analysis of experimental aerodynamic characteristics of different types of airfoils at different flow conditions categorized according to the Reynolds number has led us to a physical interpretation of the formation of laminar and turbulent flow separation.

We can conclude that the behavior of the airfoil at critical angles of attack:

- directly depends on the type of the airfoil and the local characteristics for the defined conditions of the flow;

- depends on the dynamics of the angle of attack increment at its critical values.

Based on the systematically presented results, it is possible to optimize the airfoil selection and reduce the number of iterations in the process, thus reducing the time and cost of design.

\section{References}

Cone, D.D. 1985.Maximum Lift.NASA TN D-657.

Critzos, A. 1985.Maximum Lift NACA 0012, 0015, $\alpha=00-1800,$. NACA TN 3361.

Doenhoff, A.E. Foil sections tested in two dimensions by NACA, Low-Turbulence Pressure Tunnel, T Rpt 1283. Retrieved from

www.ntrs.nasa.gov/archive/nasa/casi.ntrs.nasa.gov/19930090976.pdf

Gretchikhin, L.I. 2014. Force of the air pressure on a moving plate. Vojnotehnički glasnik/Military Technical Courier, 62(4), pp. 38-50.doi:10.5937/vojtehg62-5369

Hoerner, S.F., \& Borst, H.V. 1985. Fluid-dynamic lift: Practical information on aerodynamic and hydrodynamic lift.Vancouver: Brick Town : Hoerner.

Kostić, Č. 2010.Ispitivanje karakteristika kovita aviona u letu.Beograd: Univerzitet u Beogradu, Mašinski fakultet.

McCullough,G.B.1955. Investigation of boundary layer and stalling.NACA TN 1683.

Pinkerton, I. 1996. Maximum lift 4412 Distribution. NACA T Rpt613.

von Karman,T. 2001. Lifting-line theory for a wing in non-uniform flow.Analysis of Maximum Lift,Robert A. Millikan Library, California Institute of Technology, Pasadena, California.

\section{АЭРОДИНАМИЧЕСКИЕ ХАРАКТЕРИСТИКИ КРЫЛА} ПРИ КРИТИЧЕСКОМ УГЛЕ АТАКИ

Чедомир Л. Костич ${ }^{\mathrm{a}}$, Бошко П. Рашуо ${ }^{б}$

а Генеральный штаб Вооруженных сил Республики Сербия, РВиПВО, 204 вб, Батайница, Республика Сербия,

${ }^{б}$ Машиностроительный фракультет Белградского университета,

г. Белград, Республика Сербия

ОБЛАСТЬ: машиностроение

ВИД СТАТЬИ: обзорная статья

ЯЗЫК СТАТЬИ: английский 
Резюме:

При разработке летательных аппаратов неследует пренебрегать фрактором возникновения чрезвычайных ситуаций, а также условиями близкими критическим, так как при критическом угле атаки, обычный полет может перейти в аварийный режим.

В данной работе приведены важные фракторы, влияющие на состояние крыла в течение полета при критическом угле атаки. На основании доступных испытательных результатов и расчетов, произведен анализ поведения крыла в зависимости от условий обтекания (в соответствии с классификацией чисел Маха и Рейнольдса), формы крыла, динамики угла атаки. В работе также описано обтекание крыла при критическом увеличении угла атаки, и влияние неровностей на поверхности крыла в подобных условиях.

В данной работе также представлены фризические параметры критического режима полета, в т.ч. снижения подъемной силы и сваливания. Подробно описан процесс обтекания крыла с отрывом потока и выполнена классификация типов профелей с учетом срыва струи и поведения крыла в критическом режиме полета.

Цель работы заключается в выявлении наиболее значимых характеристик обтекания крыла при критическом угле атаки и анализе, проведенного на основах современной аэродинамики, в результате которых предлагается практическая рекомендация для выбора аэродинамического профиля. Результаты данной работы могут представлять интерес как для летчиков и инженеров, так и для образовательных и исследовательских учреждений.

Ключевые слова: аэродинамика, фрорма и вид крыла, динамика фолюидов, производительность крыла, критический угол атаки.

\section{AERODINAMIČKE KARAKTERISTIKE AEROPROFILA PRI KRITIČNIM NAPADNIM UGLOVIMA}

Čedomir Lj. Kostića ${ }^{a}$ Boško P. Rašuo ${ }^{b}$

${ }^{a}$ Generalštab Vojske Srbije, RViPVO, 204. vbr, Batajnica, Republika Srbija,

${ }^{\mathrm{b}}$ Univerzitet u Beogradu, Mašinski fakultet, Beograd, Republika Srbija

OBLAST: mašinstvo

VRSTA ČLANKA: pregledni članak

JEZIK ČLANKA: engleski

\section{Sažetak:}

Prilikom konstrukcije vazduhoplova ne sme se zanemariti ponašanje letelice u ekstremnim, odnosno blisko ekstremnim uslovima leta, kakav je let pri kritičnim napadnim uglovima, gde se normalan let može lako preobratiti u prevučen let.

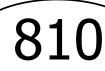


U ovom radu naglašeni su bitni činioci koji utiču na ponašanje aeroprofila u letu pri kritičnim napadnim uglovima. Na osnovu dostupnih eksperimentalnih rezultata i proračuna izvršena je analiza ponašanja aeroprofila u zavisnosti od uslova strujanja (kategorisanih prema Mahovom i Rejnoldsovom broju), oblika aeroprofila, dinamike priraštaja napadnog ugla, opstrujavanja aeroprofila sa povećanjem napadnog ugla nakon dostizanja kritične vrednosti, kao i uticaja površinskih neravnina aeroprofila pri kritičnim napadnim uglovima. Prikazano je i fizičko tumačenje pada uzgona i pojave prevučenog leta. Detaljno je opisan nastanak otcepljenja strujanja oko aeroprofila i izvršena kategorizacija aeroprofila prema tipu otcepljenja i njegovom ponašanju pri kritičnim napadnim uglovima opstrujavanja.

Cilj ovog rada jeste da na savremenim osnovama aerodinamike prikaže i obrazloži problematiku i najznačajnije osobenosti opstrujavanja aeroprofila pri kritičnim napadnim uglovima, da dâ praktične preporuke prilikom izbora aeroprofila, a može biti koristan i pilotima, inženjerima $i$ istraživačima.

Ključne reči: aerodinamika, performanse aeroprofila, dinamika fluida, oblik aeroprofila, kritični napadni ugao.

Paper received on / Дата получения работы / Datum prijema članka: 09. 04. 2015.

Manuscript corrections submitted on / Дата получения исправленной версии работы/ Datum dostavljanja ispravki rukopisa: 24. 04. 2016.

Paper accepted for publishing on / Дата окончательного согласования работы / Datum konačnog prihvatanja članka za objavljivanje: 26. 04. 2016.

(c) 2016 The Authors. Published by Vojnotehnički glasnik / Military Technical Courier (www.vtg.mod.gov.rs, втг.мо.упр.срб). This article is an open access article distributed under the terms and conditions of the Creative Commons Attribution license (http://creativecommons.org/licenses/by/3.0/rs/).

( 2016 Авторы. Опубликовано в "Военно-технический вестник / Vojnotehnički glasnik / Military Technical Courier" (www.vtg.mod.gov.rs, втг.мо.упр.срб). Данная статья в открытом доступе и распространяется в соответствии с лицензией "CreativeCommons" (http://creativecommons.org/licenses/by/3.0/rs/).

(c) 2016 Autori. Objavio Vojnotehnički glasnik / Military Technical Courier (www.vtg.mod.gov.rs, втг.мо.упр.срб). Ovo je članak otvorenog pristupa i distribuira se u skladu sa Creative Commons licencom (http://creativecommons.org/licenses/by/3.0/rs/).

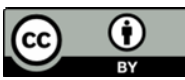

